\title{
PENINGKATKAN KOMPETENSI KEPRIBADIAN GURU DALAM MENGEMBANGKAN AKHLAK MULIA PESERTA DIDIK MELALUI PENANAMAN NILAI-NILAI KARAKTER BUDAYA JAWA
}

\author{
Nurkhan
}

\begin{abstract}
Objective is to be achieved in this study was to determine the success of planting values-based character of Javanese culture in improving personal competence of teachers, research was conducted in Dabin Sudirman is in SD 1 Bulungcangkring. To determine the success of the study, the researchers gave the pretest and reflection, reflection in cycle 1 and 2. The purpose of the pretest was to determine the initial condition of personal competence of teachers, while the reflection 1 and 2 is intended to determine the success of the action, whether the action is implemented there is increasing? what does not. in addition to validating the results of the study, researchers using observation data and observations that have been analyzed, the data will be used for the development of more lanjut.Dari data analysis proved that there is an increase in the average score rose 24.9 points from the value of the pretest or $12,44 \%$.
\end{abstract}

Keywords, Javanese culture, character, attitude, personality

* Nurkhan adalah Pengawas di UPT Pendidikan Kecamatan Jekulo Kab Kudus. 


\section{Pendahuluan}

Abad ke 21 yang ditandai dengan abad ilmu pengetahuan dan masuknya Indonesia menuju generasi emas tahun 2045, menuntut pendidikan sebagai pilar kemajuan bangsa untuk mampu mengikuti dan mengembangkan ilmu pengetahuan dan teknologi yang berkarakter. Guru sebagai ujung tombak dalam dunia pendidikan, diharapkan senantiasa cerdas dan peka terhadap berbagai pembaharuan yang terjadi dalam dunia pendidikan. Oleh karena itu guru hendaknya selalu berupaya meningkatkan wawasan keilmuan, keprofesian, dan kepribadiannya, sehingga apa yang disampaikan oleh guru kepada siswa bukan hal yang basi, tugas guru disamping meningkatkan kognitif anak, guru harus membimbing peserta didiknya untuk berkarakter (berkeprabadian) yang lebih baik dalam rangka menyongsong genersasi emas, dengan harapan agar saat itu Indonesia dapat mencapai puncak kejayaannya serta mampu menjadi model bagi negara-negara lain, dalam mengembangkan karakter atau kepribadiannya.

Pengembangan kepribadian guru perlu mendapatkan perhatian serius, karena saat ini, pengaruh negatif TI merupakan sesuatu yang tidak dapat dipungkiri lagi, dimana kemajuan teknologi, transportasi, informasi dan komunikasi menjadikan dunia seakan tiada batas. TI yang mendunia tidak hanya membawa dampak positif saja namun juga dampak negatif. Berkembangya TI membuat karakter/kepribadian menjadi makin merosot, dimana sesuatu yang dahulu dianggap tabu sekarang menjadi sesuatu yang biasa-biasa saja dan cenderung menuju hal yang negatif. Bahkan nilai-nilai karakter budaya Jawa yang memiliki nilai falsafah tinggi dianggap kuno, ketinggalan jaman dan sebagainya.

Perkembangan ilmu pengetahuan dan teknologi ternyata besar pengaruhnya terhadap kepribadian, gaya hidup, dan pola pikir manusia, dan mampu menggradasi falsafah budaya Jawa, dimana budaya Jawa kini semakin tenggelam dari bumi pertiwi disebabkan karena pembauran sosial antar bangsa. Dampaknya sulit dipungkiri, kalau kini generasi muda sering mendapat "cap" (dianggap) sudah tidak njawani lagi. Penilaian tersebut didasarkan pada perilaku negatif yang mereka perlihatkan sehari-hari yang sudah semakin jauh meninggalkan nilai-nilai 
budi pekerti. Peserta didik yang semula berahlak mulia, kini mulai terjangkit virus kemerosotan akhlak.

Berdasarkan supervisi dan observasi di Dabin Sudirman penulis menemukan beberapa masalah yang dihadapi guru yang terkait dengan kompetensi kepribadiannya yakni, (1) rendahnya rasa sosial dan kurangnya pemahaman budaya Jawa (2) belum menampilkan diri sebagai pribadi yang jujur, berakhlak mulia, dan teladan bagi peserta didik dan masyarakat (3) belum menampilkan diri sebagai pribadi yang mantap, stabil, dewasa, arif, dan berwibawa (4) belum menunjukkan etos kerja, tanggung jawab yang tinggi, rasa bangga menjadi guru, dan rasa percaya diri. (5) lemah dalam menjunjung tinggi kode etik profesi guru.

Memperhatikan data dan fakta di atas yang telah penulis paparkan, maka masalah kepribadian yang dialami guru maupun siswa di sekolah tidak dapat diselesaikan melalui kegiatan belajar mengajar saja, tetapi dimungkinkan akan dapat terselesaikan bila di sekolah diselenggarakan pembinaan khusus untuk mengembangkan kepribadian guru dan peserta didik melalui teknik menanamkan nilai-nilai karakter budaya Jawa.

Menurunnya kepribadian yang sedang melanda Indonesia ini (khususnya para pendidik) perlu segera ditanggulangi, baik secara preventif maupun kuratif. Salah satu alternatif penanggulangannya adalah dengan model penanaman nilainilai karakter budaya Jawa, alasannya nilai budaya Jawa memiliki nilai luhur yang bisa diterima semua golongan dan etnis. Agar tujuan peningkatan kepribadian guru meningkat dan berhasil maka diperlukan langkah-langkah nyata dan dukungan dari semua pihak, mulai dari pemerintah, masyarakat, khususnya generasi muda, atas dasar uraian di atas maka penulis tertarik utuk melakukan penelitian dengan model penanaman nilai-nilai karakter budaya Jawa.

Dari beberapa pendapat para ahli dapat disimpulkan bahwa kepribadian merupakan sikap seseorang yang muncul karena ada stimulus dari luar lalu seseorang tersebut merespon, respon yang dimunculkan bisa berbentuk ucapan atau perilaku, sesorang yang memiliki kepribadian kuat dia akan berpegang teguh pada pendiriannya, begitu pula sebaliknya jika seseorang kepribadiannya lemah 
maka ia akan mudah terpengaruh dengan stimulus yang ia terima. Keputusan untuk berperilaku/berbuat sesuatu sangat dipengaruhi oleh hati manusia, sedangkan kognitif hanya berfungsi, bahwa sesuatu itu benar/salah. Oleh karena itu jika hati sesorang itu buruk dimungkinkan perilakunya akan buruk juga. Atas dasar uraian tersebut maka dalam pengembangan kepribadian guru, hati harus mendapat porsi terbesar dalam pembinaan.

Ada beberapa cara dalam mengembangkan kepribadian seorang guru yakni a) melalui penaman nilai religius, 2) membiasakan berakhlak mulia setiap hari, 3) menanamkan nilai-nilai luhur karakter budaya Jawa. Dalam karya tulis ini, penulis akan mengangkat nilai-nilai budaya Jawa sebagai salah satu alternatif pengembangan kepribadian guru dengan alasan a) kalimat yang disampaikan pendek dan langsung menyentuh hati b) memiliki nilai falsafah yang tinggi, c) mudah dipahami, d) dapat diterima semua golongan dan etnis, d) terbukti efektif dalam pengembangan kepribadian.

Nilai-nilai budaya Jawa yang akan diangkat dalam karya tulis ini adalah sebagai berikut: pesan yang sering disampaikan oleh orangtua kalangan etnis Jawa kepada putra-putrinya adalah pesan (falsafah) yang diajarkan oleh Pujangga Ronggowarsito: amenangi jaman edan, ewuh aya ing pambudi, melu edan nora tahan, yen tan meluanglakoni, boya kaduman melik, kaliren wekasanipun, dilalah karsa Allah, begja-begjane kang lali, luwih begja kang eling lan waspada"(pupuh 7, Sent Kalatidha) Artinya: "Mengalami jaman gila, sukar sulit (dalam) akal ikhtiar, turut gila tidak tahan, kalau tak turut menjalaninya, tidak kebagian milik, kelaparanlah akhirnya, takdir kehendak Allah, sebahagia-bahagianya yang lupa, lebih berbahagia yang sadar serta waspada”. Syair jaman edan, dimana manusia kehilangan dasar sikap dan perilaku yang benar.

Pesan lain yang memililki nilai falsafah yang amat tinggi dan masih relevan pada jaman sekarang adalah Moh lima (tidak mau perkara lima) artinya jangan sampai melanggar perkara lima ini sebab perkara lima ini jika dilanggar akan merugikan diri sendiri, menimbulkan perilaku mal-adaptif dan meresahkan orang lain. Moh limo (main, minum, maling, madat, madon); Main artinya berjudi, bagi yang kalah akan timbul niat jahat untuk mencuri dan merampok, 
sedang yang menang akan menghambur-hamburkan uang kemenangannya; Minum artinya adalah minum minuman keras (miras) yang menjadikan orang bisa mabuk, bisa merusak pikiran dan perilakunya; Mencuri artinya adalah mengambil milik orang lain tanpa izin, perilaku mencuri akan meresahkan masyarakat dan merugikan diri sendiri; Madad menghisap ganja, morfin, narkoba dan sejenisnya orang yang sudah ketagihan narkoba sulit untuk disembuhkan, hidupnya hanya ingin berfoya-foya, malas bekerja, badannya kurus ada kecenderungan mengabaikan nasehat yang baik; Madon artinya berzina (melakukan hubungan seksual diluar nikah) dampaknya mengaburkan keturunan, terkena penyakit HIV, dan menurut agama orang tersebut akan selalu sial dan dilaknat oleh Tuhan.

Seperti falsafah Ki Hadjar Dewantoro "Ing ngarsa sung tulodo, Ing madya mangun karsa, Tut Wuri Handayani artinya di depan memberi teladan, di tengah memberi semangat/motivasi dan dari belakang memberi kekuatan". Sosro Kartono merumuskan beberapa falsafah yang terkait dengan kepribadian : a) Deling (kendel tur eling) seseorang harus pemberani tapi pakai rambu-rambu tidak ngawur, sehingga tujuan bisa tercapai. b) Ngluruk tanpa bala artinya pergi ke kancah perjuangan hidup tanpa bantuan apapun dan dari siapapun, ini menunjukkan keberanian yang luar biasa. c) Menang tanpa ngasorake artinya menang tetapi tidak merendahkan lawannya adalah bentuk seseorang yang memiliki jiwa besar. d) Sugih tanpo banda artinya kaya tanpa harta benda maksudnya seseorang bahagia walau tanpa banyak harta. Suwung pamrih tebih ajrih, artinya bersikap iklas dalam perilaku dan tidak pernah mersa takut. e) Ing donya mung kebak kangelan, sing sapa ora gelem kangelan, aja ana ing donya, artinya barangsiapa tidak mau menghadapi kesulitan jangan di dunia. f) Sinahu melu susah, melu sakit artinya merasa simpati pada orang lain. g) Pakarti asor numusi anak putu lan mbekta kesangsarane tiyang katah. artinya perbuatan jelek/hina akan menurun ke anak cucu, kejelekan kepribadian orang tua akan ditiru anak cucunya dan dampaknya bisa merugikan orang banyak. 
Metode

Penelitian ini dilaksanakan dalam bentuk Penelitian Tindakan Sekolah (PTS). Pada hakikatnya PTS merupakan penelitian yang dilakukan oleh kepala sekolah maupun pengawas di sekolah (Dabin) dengan penekanan pada penyempurnaan atau peningkatan profesional guru dalam memperbaiki pembelajaran. Namum dalam penelitian ini lebih fokus pada peningkatan kepribadian guru dalam mengembangkan akhlak mulia peserta didik berbasis nilai-nilai karakter budaya Jawa.

PTS adalah penelitian yang mengkombinasikan prosedur penelitian dengan tindakan substantif, suatu tindakan yang dilakukan dalam disiplin inkuiri, atau suatu usaha seseorang untuk memahami apa yang sedang terjadi, sambil melibat dalam sebuah proses perbaikan dan perubahan. PTS merupakan cara bagaimana sekelompok kepala sekolah atau pengawas dapat mengembangkan profesional dalam praktik pembelajaran atau pengembangan tupoksi mereka, dan belajar dari pengalaman mereka sendiri. Mereka dapat menguji-cobakan suatu gagasan perbaikan pembelajaran dan pengembangan kepribadian, dan melihat pengaruh nyata dari upaya/tindakan itu. Karena penelitian ini dilakukan oleh pengawas maka penelitian ini disebut PTSW/PTS.

PTS ini dilaksanakan dengan dua siklus setiap siklus 3 pertemuan yang berangkat dari identifikasi masalah yang dihadapi oleh kepala sekolah/guru, setiap siklus terdiri dari rencana tindakan, pelaksanaan tindakan, observasi tindakan, dan refleksi. Rangkaian kegiatan berurutan mulai dari rencana tindakan sampai dengan refleksi disebut satu siklus penelitian. Jika dalam setiap refleksi ditemukan masalah yang dihadapi guru, baik masalah baru maupun masalah lama yang dianggap mengganggu tercapainya PTS, maka penulis dapat mengidentifikasi, menganalisis, dan merumuskan masalah tersebut. Selanjutnya, penulis dapat melakukan penelitian untuk perbaikan lebih lanjut pada siklus berikutnya, yang dimulai dari penyusunan rencana tindakan sampai dengan refleksi. Namun, jika dalam refleksi pada siklus tertentu tidak terjadi kendala dan tujuan PTS telah terealisasikan atau tercapai, maka penelitian dihentikan, tidak perlu dilanjutkan. Adapun langkah- langkah pelaksanaan PTS dilakukan melalui empat tahap, yakni 
(1) perencanaan tindakan, (2) pelaksanaan tindakan, (3) observasi dan interpretasi, dan (4) analisis dan refleksi.
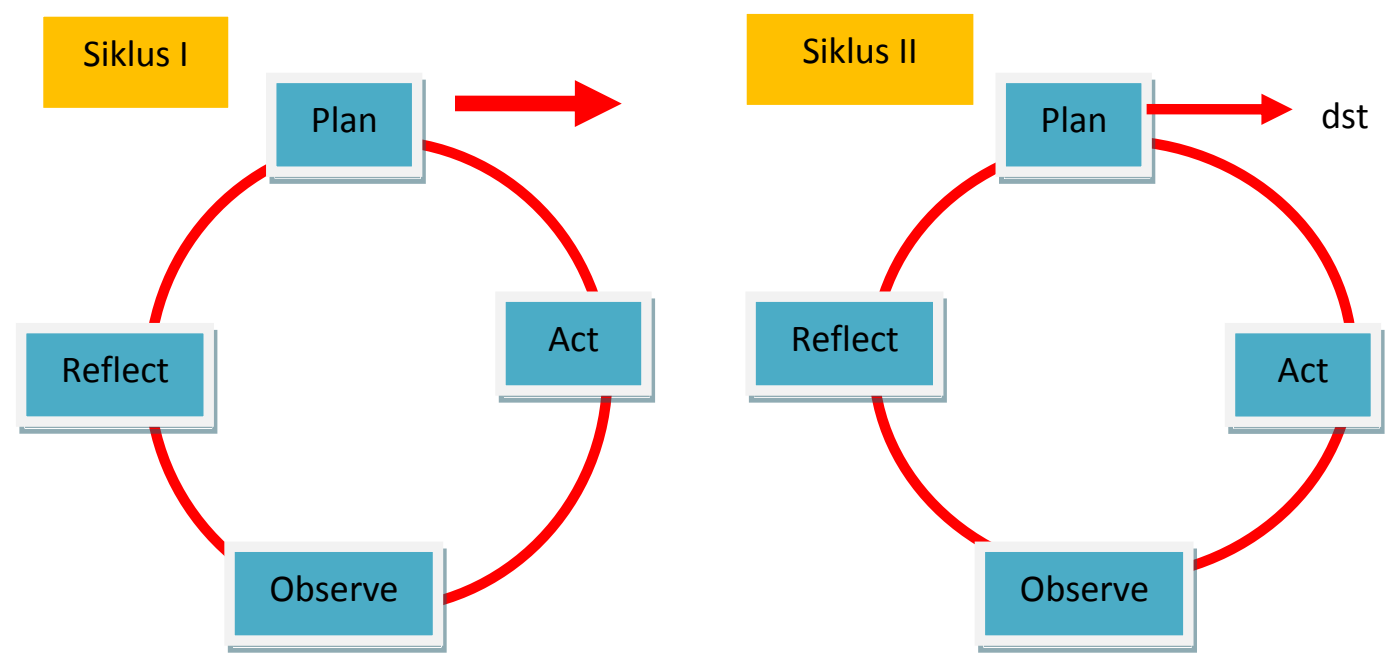

\section{Gambar 1 Siklus Penelitian Tindakan Sekolah (PTS)}

Keterangan: 1. Plan (perencanaan tindakan) 2. Act (pelaksanaan tindakan) 3 Observe (observasi dan interpretasi) 4. Reflect (analisis dan refleksi).

Sumber data penelitian meliputi tempat dan kegiatan penelitian, yakni Dabin Sudirman sebagai tempat penelitian sedangkan guru sebagai subjek penelitian dan beberapa masalah yang dialami oleh kepala sekolah maupun guru kemudian penulis mencatat segala sesuatu yang terjadi baik sebelum tindakan (survey awal) maupun setelah dilaksanakan pembinaan intensif, data tersebut akan digunakan sebagai dasar tindakan.

Instrumen penelitian adalah alat atau fasilitas yang digunakan oleh penulis dalam mengumpulkan data agar pekerjaannya lebih mudah dan hasilnya lebih baik, dalam arti lebih cermat, lengkap, serta sistematis sehingga lebih mudah diolah, disajikan, dipahami oleh pembaca. Instrumen pengumpul data dalam penelitian digunakan untuk mengumpulkan data kualitatif atau data kuantitatif. Pada penelitian ini penulis mengunakan data kualitatif, sedangkan data kuantitatif dibutuhkan untuk memperjelas data yang terkumpul. 
Hasil

Untuk mengetahui kepribadian guru sebelum diberi perlakuan/pembinaan dari peneliti, penulis memberikan pretes dalam bentuk tes skala psikologis kepada guru guna memperoleh gambaran umum tentang kepribadian guru, hal ini penting karena pretes akan dipakai untuk membedakan, apakah ada peningkatan antara sebelum diberikan perlakuan dengan sesudah mendapat perlakuan.

Tabel 1. Profil Awal (Pretes)

\begin{tabular}{|c|l|c|c|}
\hline No. & \multicolumn{1}{|c|}{ Nama } & Evaluasi Awal & Kriteria \\
\hline 1 & Zaenal Aripin,S.Pd, SD & 120 & Kurang \\
\hline 2 & Mariyun,S.Pd, SD & 171 & Tinggi \\
\hline 3 & Kusnin,S.Pd,SD & 131 & Sedang \\
\hline 4 & Asmiyati, S.Pd,SD & 118 & Kurang \\
\hline 5 & Markonah, S.Pd, SD & 127 & Sedang \\
\hline 6 & Karsini, S.Pd SD & 120 & Kurang \\
\hline 7 & Jumadi, S.Pd,SD & 117 & Kurang \\
\hline 8 & Rusidi,S.Pd, SD & 119 & Kurang \\
\hline 9 & Indra Wiyono,S.Pd & 156 & Sedang \\
\hline 10 & Sulikhah, S.Pd, SD & 160 & Sedang \\
\hline 11 & Noorhidayat,S.Pd SD & 137 & Sedang \\
\hline 12 & Kasmirin, S.Pd,SD & 119 & Kurang \\
\hline 13 & Sri Anggorokasih,S.Pd & 142 & Sedang \\
\hline 14 & Eko Harsona,S.Pd, SD & 173 & Tinggi \\
\hline 15 & Sutinem,S.Pd,SD & 160 & Sedang \\
\hline 16 & Masrurokh, S.Pd, SD & 151 & Sedang \\
\hline 17 & Rochmat, S.Pd, SD & 135 & Sedang \\
\hline 18 & Sutono,S.Pd & 117 & Sedang \\
\hline
\end{tabular}

Tabel 2. Prosentase Kondisi Awal Kepribadian Guru

\begin{tabular}{|c|c|c|c|}
\hline Rentang Nilai & Jumlah Guru & Prosentase & Kreteria \\
\hline 161 s/d 200 & 2 & $11,11 \%$ & Tinggi \\
\hline 121 s/d 160 & 10 & $55,55 \%$ & Sedang \\
\hline 81 s/d 120 & 6 & $33,33 \%$ & Kurang \\
\hline 40 s/d 80 & 0 & $0 \%$ & Rendah \\
\hline
\end{tabular}

Tabel di atas menunjukkan jumlah/frekuensi kepribadian guru pada kategori tinggi sebanyak 2 guru (11,11\%), kategori sedang 10 guru (55,55\%), kategori kurang 6 guru (33.33\%), dan kategori rendah 0 guru (0\%). Data ini 
memperkuatasumsi dasar bahwasanya tingkat kompetensi kepribadian guru perlu ditingkatkan.

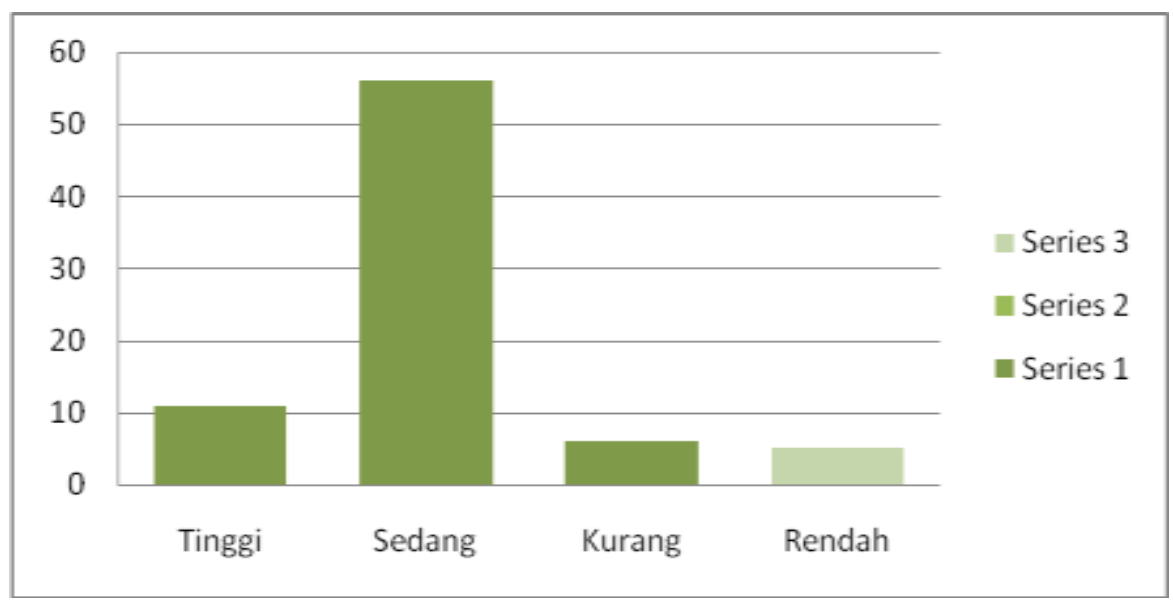

Grafik 1. Hasil Skala Psikologis Pretes

\section{Siklus I}

Siklus I dilaksanakan tiga kali pertemuan, untuk mengukur hasil tindakan siklus I penulis, pada siklus ini peneliti menggunakan metode ceramah dan diskusi, kemudian memberikan evaluasi dengan menggunakan instrumen skala psikologis, tujuan pengukuran ini adalah untuk mengetahui peningkatan kepribadian guru setelah mendapat perlakuan/pembinaan. Dibawah ini dipaparkan hasil postes siklus I.

Tabel 3. Hasil Postes Siklus 1

\begin{tabular}{|c|l|c|c|}
\hline No. & \multicolumn{1}{|c|}{ Nama } & PosTes & Kriteria \\
\hline 1 & Zaenal Aripin,S.Pd, SD & 133 & Kurang \\
\hline 2 & Mariyun,S.Pd, SD & 175 & Tinggi \\
\hline 3 & Kusnin,S.Pd,SD & 155 & Sedang \\
\hline 4 & Asmiyati, S.Pd,SD & 121 & Kurang \\
\hline 5 & Markonah, S.Pd, SD & 136 & Sedang \\
\hline 6 & Karsini, S.Pd SD & 131 & Kurang \\
\hline 7 & Jumadi, S.Pd,SD & 163 & Sedang \\
\hline 8 & Rusidi,S.Pd, SD & 132 & Kurang \\
\hline 9 & Indra Wiyono,S.Pd & 160 & Sedang \\
\hline 10 & Sulikhah, S.Pd, SD & 165 & Sedang \\
\hline 11 & Noorhidayat,S.Pd SD & 162 & Sedang \\
\hline 12 & Kasmirin, S.Pd,SD & 125 & Sedang \\
\hline 13 & Sri Anggorokasih,S.Pd & 165 & Sedang \\
\hline 14 & Eko Harsona,S.Pd, SD & 175 & Tinggi \\
\hline 15 & Sutinem,S.Pd,SD & 162 & Sedang \\
\hline 16 & Masrurokh, S.Pd, SD & 160 & Sedang \\
\hline 17 & Rochmat, S.Pd, SD & 160 & Sedang \\
\hline
\end{tabular}




\begin{tabular}{l|l|l|l|}
18 & Sutono,S.Pd & 121 & Sedang \\
\hline
\end{tabular}

Tabel 4. Prosentase Hasil Postes Siklus I

\begin{tabular}{|c|c|c|c|}
\hline Rentang Nilai & Jumlah Guru & Prosentase & Kreteria \\
\hline $41 \mathrm{~s} / \mathrm{d} 50$ & 7 & $38,88 \%$ & Tinggi \\
\hline $31 \mathrm{~s} / \mathrm{d} 40$ & 10 & $55,55 \%$ & Sedang \\
\hline $21 \mathrm{~s} / \mathrm{d} 30$ & 1 & $5,55 \%$ & Kurang \\
\hline $10 \mathrm{~s} / \mathrm{d} 20$ & 0 & $0 \%$ & Rendah \\
\hline
\end{tabular}

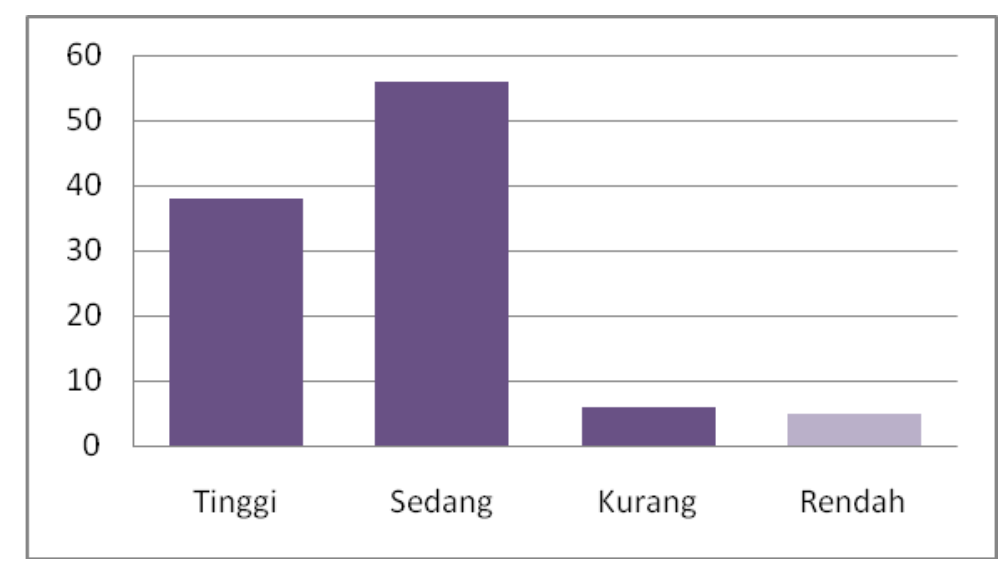

Grafik 2. Hasil Prosentase Siklus 1

Berdasar data di atas maka dapat disimpulkan bahwa hasil pretes, postes satu, sampai postes tiga dan refleksi I menunujukkan adanya peningkatan pada semua indikator namun hasilnya belum signifikan, sehingga dalam penelitian tindakan ini peneliti melanjutkan pada siklus kedua.

\section{Siklus kedua}

Siklus kedua dilaksanakan untuk memperbaiki kekurangan pada siklus 1, perbaikan dilakukan dengan mengubah metode pembinaan, yakni metode tugas mandiri, menayangkan video, dan menyampaikan kisah nyata, bahwa kepribadian yang buruk akan merugikan diri sendiri dan orang lain, khususnya di sekolah. Evaluasi diberikan dengan menggunakan instrumen skala psikologis, untuk mengukur peningkatan kepribadian guru, setelah mendapat perlakuan/pembinaan kepribadian, di bawah ini dipaparkan hasil evaluasi siklus II. 
Tabel 5. Hasil Postes Refleksi Siklus 2

\begin{tabular}{|c|l|c|c|}
\hline No. & \multicolumn{1}{|c|}{ Nama } & Refleksi & Kriteria \\
\hline 1 & Zaenal Aripin,S.Pd, SD & 161 & Tinggi \\
\hline 2 & Mariyun,S.Pd, SD & 172 & Tinggi \\
\hline 3 & Kusnin,S.Pd,SD & 171 & Tinggi \\
\hline 4 & Asmiyati, S.Pd,SD & 158 & Sedang \\
\hline 5 & Markonah, S.Pd, SD & 157 & Tinggi \\
\hline 6 & Karsini, S.Pd SD & 157 & Sedang \\
\hline 7 & Jumadi, S.Pd,SD & 157 & Sedang \\
\hline 8 & Rusidi,S.Pd, SD & 171 & Tinggi \\
\hline 9 & Indra Wiyono,S.Pd & 158 & Sedang \\
\hline 10 & Sulikhah, S.Pd, SD & 164 & Tinggi \\
\hline 11 & Noorhidayat,S.Pd SD & 167 & Tinggi \\
\hline 12 & Kasmirin, S.Pd,SD & 149 & Sedang \\
\hline 13 & Sri Anggorokasih,S.Pd & 152 & Sedang \\
\hline 14 & Eko Harsona,S.Pd, SD & 173 & Tinggi \\
\hline 15 & Sutinem,S.Pd,SD & 170 & Tinggi \\
\hline 16 & Masrurokh, S.Pd, SD & 161 & Tinggi \\
\hline 17 & Rochmat, S.Pd, SD & 165 & Tinggi \\
\hline 18 & Sutono,S.Pd & 147 & Sedang \\
\hline
\end{tabular}

Tabel 6. Prosentase Hasil Evaluasi Siklus 2

\begin{tabular}{|c|c|c|c|}
\hline Rentang Nilai & Jumlah Guru & Prosentase & Kreteria \\
\hline $41 \mathrm{~s} / \mathrm{d} 50$ & 11 & $61 \%$ & Tinggi \\
\hline $31 \mathrm{~s} / \mathrm{d} 40$ & 7 & $39 \%$ & Sedang \\
\hline $21 \mathrm{~s} / \mathrm{d} 30$ & 0 & $0 \%$ & Kurang \\
\hline $10 \mathrm{~s} / \mathrm{d} 20$ & 0 & $0 \%$ & Rendah \\
\hline
\end{tabular}




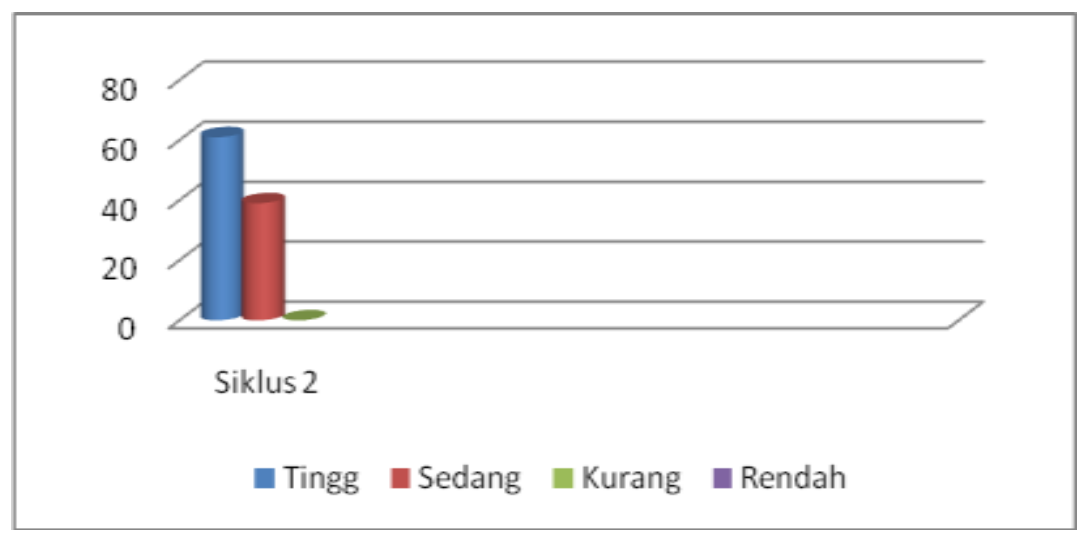

Grafik 4 Posrentase Hasil Siklus 2

Evaluasi diberikan pada siklus I dan II dengan menggunakan instrumen skala psikologis, untuk mengukur apakah ada peningkatan kepribadian antara siklus satu dengan siklus dua ? di bawah ini dipaparkan hasil nilai mulai pretes, siklus satu dan siklus dua.

Tabel 7 Hasil Pretes, Pos tes dan Refleksi 2

\begin{tabular}{|c|c|c|c|c|c|c|c|c|c|c|c|c|}
\hline & & \multicolumn{4}{|c|}{ Pretes } & \multicolumn{3}{|c|}{ Refleksi 1} & \multicolumn{3}{c|}{ Refleksi 2} & \multicolumn{2}{c|}{ Peningkatan } \\
\cline { 3 - 14 } NO & Nama & Nilai & F $\%$ & Kret & Nilai & F $\%$ & Kret & Nilai & F $\%$ & Kret & N & F $\%$ \\
\hline 1 & ZA & 120 & 60 & KR & 133 & 66,5 & SD & 161 & 80,5 & TG & 41 & 20,5 \\
\hline 2 & MR & 171 & 85,5 & T & 175 & 87,5 & TG & 172 & 86 & TG & 1 & 0,5 \\
\hline 3 & KS & 131 & 65,5 & KR & 155 & 77,5 & SD & 171 & 85,5 & TG & 40 & 20 \\
\hline 4 & AS & 118 & 59 & KR & 121 & 60,5 & SD & 168 & 84 & TG & 50 & 25 \\
\hline 5 & MK & 127 & 63,5 & SD & 136 & 68 & SD & 157 & 78,5 & SD & 30 & 15 \\
\hline 6 & KR & 120 & 60 & KR & 131 & 65,5 & SD & 157 & 78,5 & SD & 37 & 18,5 \\
\hline 7 & JM & 117 & 58,5 & KR & 163 & 81,5 & SD & 157 & 78,5 & SD & 40 & 20 \\
\hline 8 & RS & 119 & 59,5 & KR & 132 & 66 & SD & 171 & 85,5 & TG & 52 & 26 \\
\hline 9 & IW & 156 & 78 & SD & 160 & 80 & SD & 158 & 79 & SD & 2 & 1 \\
\hline 10 & SL & 160 & 80 & SD & 165 & 82,5 & SD & 164 & 82 & TG & 4 & 2 \\
\hline 11 & NH & 137 & 68,5 & SD & 162 & 81 & SD & 167 & 83,5 & TG & 30 & 15 \\
\hline 12 & KS & 119 & 59,5 & KR & 125 & 62,5 & SD & 149 & 74,5 & SD & 30 & 15 \\
\hline 13 & SA & 142 & 71 & SD & 165 & 82,5 & TG & 152 & 76 & SD & 10 & 5 \\
\hline 14 & EH & 173 & 86,5 & TG & 175 & 87,5 & TG & 174 & 87 & TG & 1 & 0,5 \\
\hline 15 & ST & 160 & 80 & SD & 162 & 81 & TG & 170 & 85 & TG & 10 & 5 \\
\hline 16 & MS & 151 & 75,5 & SD & 160 & 80 & SD & 161 & 80,5 & TG & 10 & 5 \\
\hline 17 & RS & 135 & 67,5 & SD & 160 & 80 & SD & 165 & 82,5 & TG & 30 & 15 \\
\hline 18 & SN & 117 & 58,5 & KR & 121 & 60,5 & KR & 147 & 73,5 & SD & 30 & 15 \\
\hline & Rata2 & 137 & 68,7 & SD & 150 & 75 & SD & 162 & 81,1 & TG & 24,9 & 12,44 \\
\hline
\end{tabular}




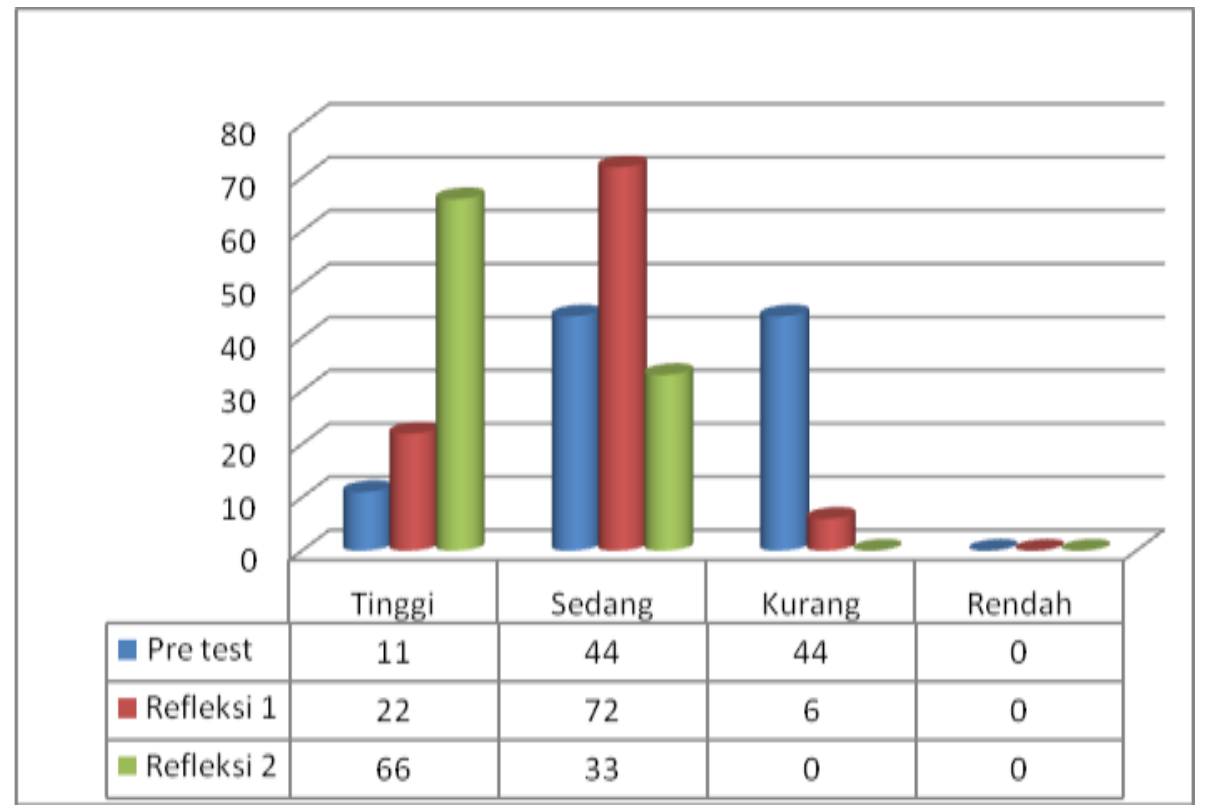

Grafik 2 Perbandingan Antara Pre tes, Refleksi 1 dan Refleksi 2

Berdasarkan grafik di atas terlihat bahwasanya kepribadian guru pada semua indikator mengalami peningkatan (nilai postes lebih tinggi dari nilai pretes). Ketercapaian hasil tersebut berkat bimbingan intensif yang dilakukan peneliti, hasil penelitian tindakan sekolah memiliki dampak positif dalam meningkatkan kepribadian guru Dabin Sudirman.

\section{Pembahasan Produk Akhir}

Berdasarkan analisis hasil pembinaan intensif yang dilaksanakan penulis di Dabin Sudirman, membuktikan bahwa pembinaan intensif berbasis nilai-nilai karakter budaya Jawa efektif dalam meningkatkan kepribadian guru Dabin Sudirman. Indikasi keberhasilan proses pelaksanaan pembinaan dapat dilihat dari peran yang dilaksanakan oleh penulis dan guru pada setiap siklus, baik siklus1 maupun siklus 2 menunujukkan peneingkatan seperti pada tabel di atas. Peningkatan sikap jujur siswa adalah sebesar 24,9 poin atau sama dengan $12,44 \%$. 
Tabel 9. Peningkatan Pretes Dengan Siklus 2

\begin{tabular}{|c|c|c|c|}
\hline NO & Kegiatan & Poin & Prosentase \\
\hline 1 & Pre test & 137 & 68,7 \\
\hline 2 & Siklus 1 & 150 & 75 \\
\hline 3 & Siklus II & 162 & 81,1 \\
\hline & Peningkatan Pre \& Sik 2 & 24,9 & 12,4 \\
\hline
\end{tabular}

\section{SIPULAN DAN SARAN}

\section{Simpulan}

Berdasarkan hasil analisis data dan observasi yang dilakukan oleh peneliti mulai dari tahap awal sampai pada siklus 2 dapat dirumuskan beberapa simpulan sebagai berikut a) pembinaan intensif kompetensi kepribadian melalui penanaman nilai-nilai karakter budaya Jawa bagi guru di dabin Sudirman terbukti dapat meningkatkan kepribadian guru dalam mengembangkan akhlak mulia peserta didik. Peningkatan tersebut diketahui melalui hasil evaluasi pretes dan postes kenaikan skor 24,9 poin atau naik $12,44 \%$. Hal ini menunjukkan bahwa tujuan pembinaan intensif yang dilaksanakan peneliti mulai. siklus 1 dan 2 telah tercapai. b) pembinaan kepribadian melalui penanaman nilai-nilai karakter budaya Jawa secara efektif dapat meningkatkan kepribadian guru pada semua indikator yakni kognitif, afektif, konatif. Simpulan ini didasarkan pada perbedaan antara skor evaluasi awal dan refleksi 2, dimana ada peningkatan skor kepribadian guru sebelum dan sesudah diberi pembinaan intensif melalui penanaman berbasis nilai karakter budaya Jawa (rata-rata) naik sebesar 24,9 poin atau sama dengan $12,44 \%$. artinya ada peningkatan antara sebelum diberikan pembinaan dan sesudah diberikan pembinaan. Oleh karena itu dapat disimpulkan bahwa pembinaan intesif yang dilakukan peneliti mulai siklus 1 dan 2 dengan model penanaman nilai-nilai karakter budaya Jawa terbukti efektif dalam meningkatkan kepribadian guru dabin Sudirman UPT Pendidikan Kec Jekulo. 


\section{Saran}

Bagi Sekolah diharapkan dapat memberikan kesempatan, dukungan, dan atau fasilitas kepada guru untuk mengembangkan nilai-nila karakter berbasis budaya Jawa dalam meningkatkan akhlak mulia peserta didik. Sekolah hendaknya lebih inovatif dalam menggali nilai budaya Jawa, serta aktif dalam membiasakan peningkatkan akhlak mulia peserta didik.

Bagi Guru tidak boleh mengesampingkan kepribadiannya, tetapi sebaliknya harus serius mengembangkannya, karena tinggi-rendahnya tingkat kepribadian guru akan berdampak pada kualitas perkembangan akhlak peserta didik. Sehubungan dengan pentingnya masalah kepribadian guru, penanganannya dengan menggunakan pembinaan intensif berbasis nilai budaya Jawa dapat diprogramkan secara periodik terutama terhadap guru-guru yang skala kepribadiannya masuk pada kategori kurang dan rendah.

\section{DAFTAR PUSTAKA}

Agustini. 2007. Cermin Retak Budaya Bangsa (Sebuah Refleksi Dengan Pendekatan Budaya Jawa). Yogyakarta : Andi Offset.

Aksan, 1995. Gema Suara Sosro Kartono. Djoyo boyo

Arikunto, S. 2006. Prosedur Penelitian Suatu Pendekatan Praktek (Edisi Revisi). Jakarta: Rineka Cipta.

Azwar, S. 2012. Sikap Manusia: Teori dan Pengembangannya. Yogyakarta: Pustaka Pelajar.

Endraswara, S. 2003. Budi Pekerti dalam Budaya Jawa . Yogyakarta : CV. Adipura.

Hadi, S. 2004. Metodologi Reasearch. Yogyakarta: Andi Offset.

Haq, MZ. 2011. Mutiara Hidup Manusia Jawa. Malang : Aditya Media Khalim.2009.Tradisi Lisan Masyarakat Jawa. Semarang : Primamedia Offset.

Kartono, K. 2011. Kamus Lengkap Psikologi. Jakarta: PT Raja Grafindo Persada Lickona, Thomas. 2012. Character Matters.Terjemahan Juma Abdu Wamaungo Jakarta: Bumi Aksara.

Muslich KS. 2006. Moral Islam dalam Serat Piwulang Pakubuwono IV. Yogyakarta : Global Pustaka Utama.

L P M P. 2011, Pendidikan Karakter Bangsa, LPMP Jawa Tengah. 
